\title{
Isolating system using U Shaped steel damper
}

\author{
Siripuram Vamshisheela, Atulkumar Manchalwar \\ ${ }^{1}$ M Tech Student, Gokaraju Rangaraju Institute of Engineering and Technology, Hyderabad, India \\ ${ }^{2}$ Associate Professor, Gokaraju Rangaraju Institute of Engineering and Technology, Hyderabad, India
}

\begin{abstract}
In this work the performance of U-Shaped Steel Isolator is evaluated for a 5-story building subjected to seismic and blast vibrations. The structure is analysed using SAP 2000 software and a nonlinear time history analysis is carried out. The effectiveness of using base isolation is studied by comparing the structural responses of the building with isolator and without isolator and noticeable difference was observed. As the U-Shaped isolator absorbs the energy in all directions, it effectively controls the structural responses. In this study, the building is subjected to four different seismic and four different blast induced ground motions. It was observed that by the use of supplementary energy device there is reduction in top story acceleration, base shear and less deformation in the structure. This study concludes that the use of isolator has been effective in minimizing structural responses.
\end{abstract}

\section{Introduction}

In the field of Earthquake Engineering, many methodologies are being developed to safeguard the structure \& to control the responses in the structure. During an Earthquake and blast, a lot of energy is being created which cause damage to the structural assets and human life. To protect the structure from such natural calamities many techniques were developed now a days and being implemented to lesser the damages and withstand safety against such large forces. Base Isolation is one such implementation where the building is supplemented with passive, semi active and active control devices. In the recent years, many researchers have started working in civil engineering field by evaluating the performance of Base Isolation, assessing the condition of the building. Praveen and Gopalakrishna has focussed mid-rise configured models with and without setbacks under earthquake vibrations to evaluate seismic performance. Vinothini and Elavenil presents the response of a concrete framed structure of high-rise model which is loaded dynamically is analysed in SAP 2000. The dynamic responses of steel structures during external detonations through different charge weights at $3 \mathrm{~m}$ standoff distances is studied by Mohammad Abdallah. Omprakash and Atul Manchalwar has supplemented a RC building with X-Plate damper and evaluated the structural responses which is subjected to blast and earthquake forces. Figuli et al., analysed blast loaded steel structure and derives an issue based on explosive and explosion type under dynamic load. A detailed computational study of a 2-story steel frame is considered to show the capacity of Nitinol \& SMA damper to minimise vibrations in the structure when subjected to blast is studied by Dutta and Mujunder.

In this research behaviour of five story model subjected to both Earthquake and Blast induced ground motions are studied with and without Isolator. For this purpose, Ushaped steel damper is used as an isolator and supplemented to the building and non-linear dynamic analysis i.e., time history analysis is conducted for earthquake and blast ground acceleration data.

\subsection{U- Shaped Damper}

During a blast, large amount of energy is released and shock waves are developed which are compressive in nature. As Earthquake and Blasts are two different scenarios, U-shaped damper is used in this research as to control the responses because the structure undergoes deformation in every direction 360 degrees, as to absorb the energy $U$ damper has been used and evaluated its performance for different Earthquakes and blasts. Homogeneous damping is required as the building deforms in horizontal direction, as steel is plastic in nature it dissipates the energy in all directions for the ground vibrations.

Table. 1. Properties of U-Shaped Isolator for 4 arms

\begin{tabular}{|c|c|c|c|}
\hline \multicolumn{4}{|c|}{ Properties } \\
\hline $\begin{array}{c}\text { 1.Yield } \\
\text { Force } \\
(\mathrm{N})\end{array}$ & $\begin{array}{c}\text { 2.Initial } \\
\text { Stiffness } \\
(\mathrm{ki})(\mathrm{N} / \mathrm{m})\end{array}$ & $\begin{array}{c}\text { 3.Post yield } \\
\text { Stiffness }(\mathrm{kp}) \\
(\mathrm{N} / \mathrm{m})\end{array}$ & $\begin{array}{c}\text { 4.Post yield } \\
\text { stiffness } \\
\text { ratio }(\alpha)\end{array}$ \\
\hline
\end{tabular}




\begin{tabular}{|l|l|l|l|}
\hline $112 \times 10^{3}$ & $5920 \times 10^{3}$ & $100 \times 10^{3}$ & 0.0169 \\
\hline
\end{tabular}

Table. 2. Earthquakes records taken from FEMA $695 \mathrm{P}$

\begin{tabular}{|l|l|}
\hline EARTHQUAKE & YEAR \\
\hline Kern County Earthquake & July 21, 1952 \\
\hline $\begin{array}{l}\text { Loma Prieta- Oakland } \\
\text { Outer Harbour Wharf }\end{array}$ & October 17, 1989 \\
\hline $\begin{array}{l}\text { San Pernando } \\
\text { Earthquake- Pacoima } \\
\text { Dam } \quad \text { February 9, 1971 }\end{array}$ \\
\hline $\begin{array}{l}\text { Parkfield Earthquake- } \\
\text { Cholame, Shandon }\end{array}$ & June 27, 1966 \\
\hline
\end{tabular}

For the numerical analysis, the acceleration data include most commonly cited four different Earthquake records (Kern County Earthquake, Loma Prieta -Oakland Outer Harbour Wharf, San Fernando Earthquake, Parkfield Earthquake) Which were taken from FEMA P-695.

\subsection{Ground Motion Data}

Hinman, Carvalho and Battista have calculated the accelerations of blasts for different charge weights $\ddot{x} g(t)$ which is an exponential decay function given as follows

$\ddot{x} g(t)=-\frac{1}{t d} v e^{\frac{-1}{t d}}$

In the above equation, td is the time for arrival which is evaluated using the formula $t d=R / C$, here $R$ is the distance from the point of charge $(\mathrm{m})$ and $\mathrm{C}$ is velocity of propagated wave $(\mathrm{m} / \mathrm{s})$. $\mathrm{V}$ is the maximum velocity of a particle, these empirical formulae to calculate ' $\mathrm{V}$ ' is proposed by Kumar et al., derived from field data available for different cases is given as

$v=\frac{f^{0.642} S D^{-1.463}}{\gamma D}$

Where, $f$ is uniaxial compressive strength of granite rock deposit and taken as $\mathrm{f}=70 \times 10^{6} \mathrm{~Pa}, \mathrm{SD}$ (Scaled Distance) which is given as $R / \sqrt{Q}, \mathrm{R}$ is the mass of charge. The charge weight $\mathrm{Q}$ in present study is taken as $10 \times 10^{3} \mathrm{~kg}$, $25 \times 10^{3} \mathrm{~kg}, 50 \times 10^{3} \mathrm{~kg}$ and $75 \times 10^{3} \mathrm{~kg}$.

$\gamma D$ is the average mass density taken as $26.50 \times 10^{3}$ $\mathrm{KN} / \mathrm{m} 3$ and young's modulus $\mathrm{E}=73900 \mathrm{MPa}$, which depends on the material properties of granite.

\section{Building Model}

In the present study, a simple low-rise building, a 5-story base isolated structure is adopted from Zhang and Philips (2016). The model used in the study is a lumped mass system. The variables of the model are listed in the table. Under all external dynamic excitations, the model is assumed to be remained linearly elastic which facilitates with a scenario where non-structural components may be damaged and non-structural components remain functional.

This structure is modelled using Sap 2000 software for isolated base and another for fixed. The natural period of the building with which base is fixed is $0.54 \mathrm{sec}$ whereas, for the base isolated model the fundamental natural period is $2.5 \mathrm{sec}$. By supplementing the building with baseisolation device, there is a shift in the natural period of the building such that maximum amount of energy is dissipated during an earthquake and blast vibrations.

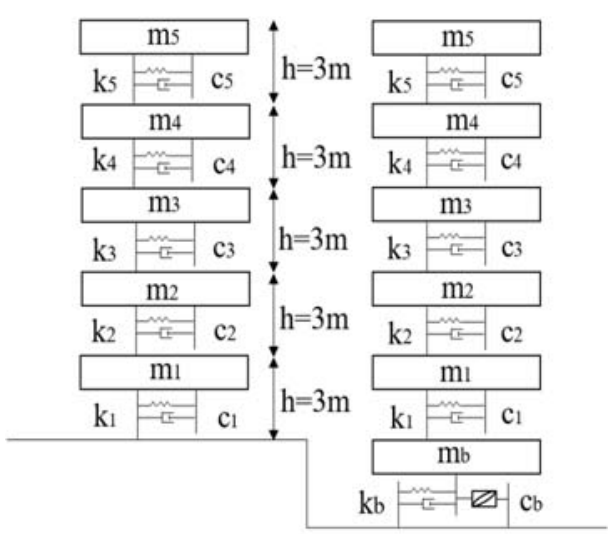

Fig. 1. Diagrammatic representation of five-story model

Table. 3. Variables of five-story building

\begin{tabular}{|l|c|c|c|}
\hline Stories & $\begin{array}{c}\text { Mass on } \\
\text { Floor M } \\
\text { (tons) }\end{array}$ & $\begin{array}{c}\text { Story's } \\
\text { Stiffness K } \\
(\mathbf{N} / \mathbf{m})\end{array}$ & $\begin{array}{c}\text { Damping } \\
\text { Coefficient C } \\
(\mathbf{k g} / \mathbf{s})\end{array}$ \\
\hline Floor 1 & $\mathrm{m}_{1}=53.073$ & $\mathrm{k}_{1}=101196 \times 10^{3}$ & $\mathrm{c}_{1}=348.14 \times 10^{3}$ \\
\hline Floor 2 & $\mathrm{m}_{2}=53.073$ & $\mathrm{k}_{2}=87279 \times 10^{3}$ & $\mathrm{c}_{2}=301.38 \times 10^{3}$ \\
\hline Floor 3 & $\mathrm{m}_{3}=53.073$ & $\mathrm{k}_{3}=85863 \times 10^{3}$ & $\mathrm{c}_{3}=296.18 \times 10^{3}$ \\
\hline Floor 4 & $\mathrm{m}_{4}=53.073$ & $\mathrm{k}_{4}=74862 \times 10^{3}$ & $\mathrm{c}_{4}=259.81 \times 10^{3}$ \\
\hline Floor 5 & $\mathrm{m}_{5}=53.073$ & $\mathrm{k}_{5}=57177 \times 10^{3}$ & $\mathrm{c}_{5}=197.45 \times 10^{3}$ \\
\hline
\end{tabular}

The Isolator parameters such as initial stiffness, post yield stiffness is calculated by standard formulae of Time period i.e., $\mathrm{Tb}=2 \pi \sqrt{\frac{M}{K}}$ and post yied stiffness ratio $\alpha=\frac{k p}{k i}$ 
where, $\alpha$ is taken as 0.1 and $\mathrm{Tb}$ is taken as 2, 2.5 and $3 \mathrm{sec}$. Yield strength of the isolated is calculated by equating the ratio of $\frac{Q}{W}$ to $0.05,0.075$ and 0.1 where, $\mathrm{W}$ is the total weight of the building.

\section{Dynamic Responses}

By the use of U-Shaped steel Isolator there is reduction in the responses like accelerations at top story level under dynamic excitations. The graphical representation shows the amount of reduction in acceleration for four different Earthquake and Blast induced ground motions for a building with damper and without damper.

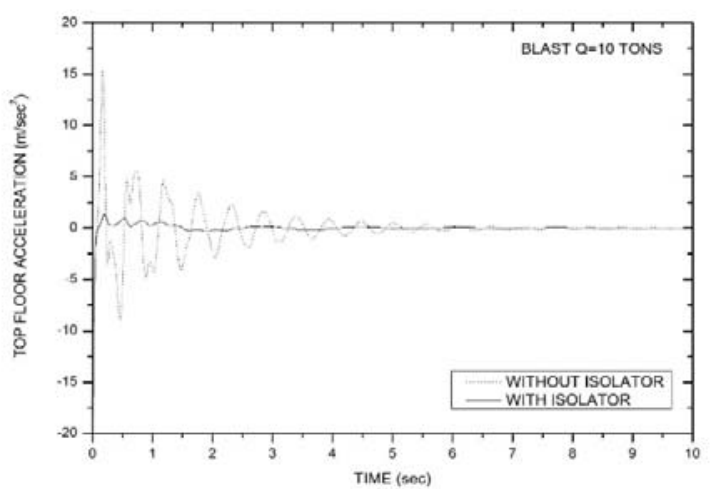

2(a)

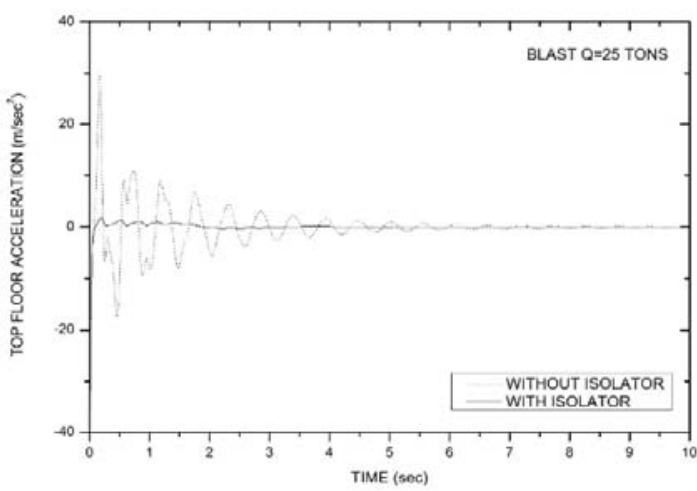

2(b)

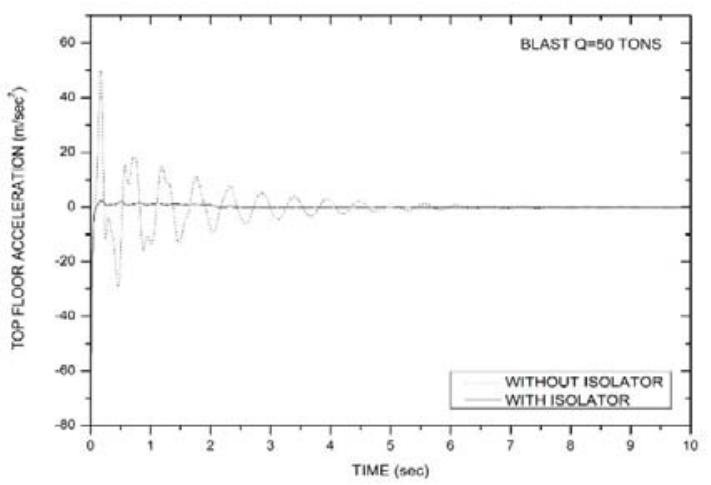

2(c)
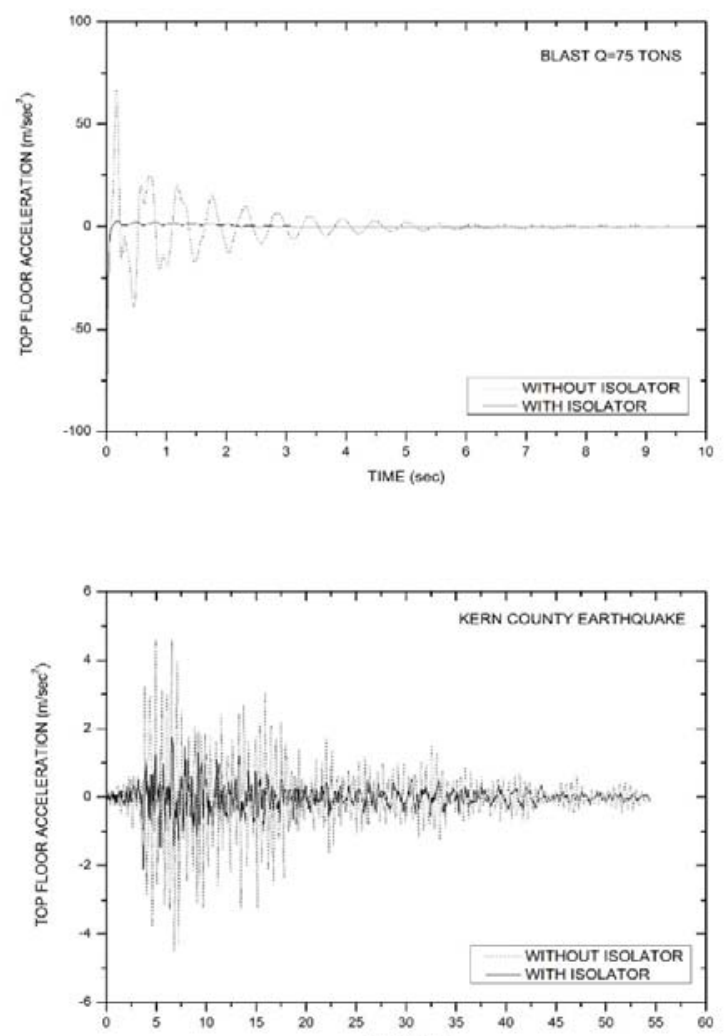

2(e)

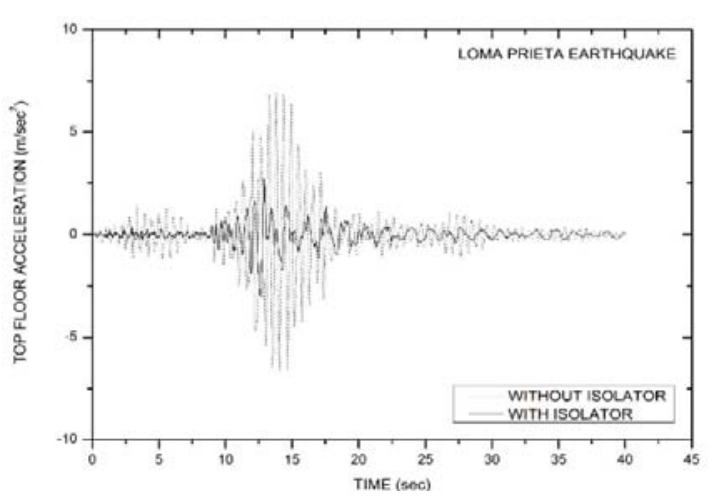

2(f) 

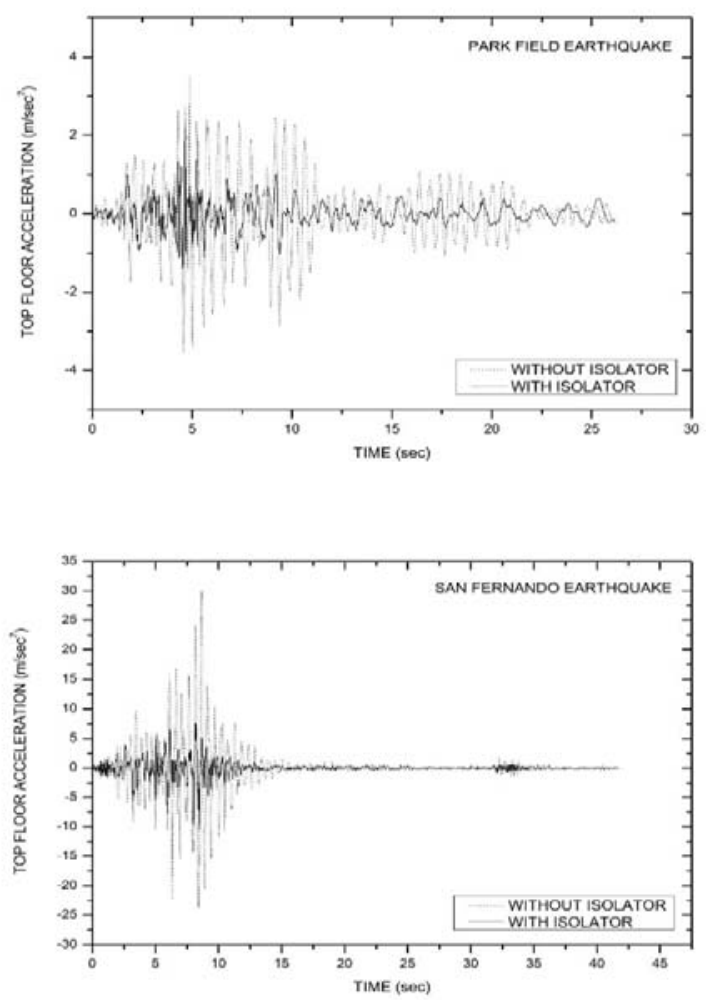

Fig. 2

U-Shaped Isolator is also effer Icing Base Shear values and thus it enhances the performance of the structure. The results are shown below in the form of graphs for different Earthquakes and four different blast induced ground motions and comparison was made for building with isolator and without isolator by performing nonlinear time history analysis.

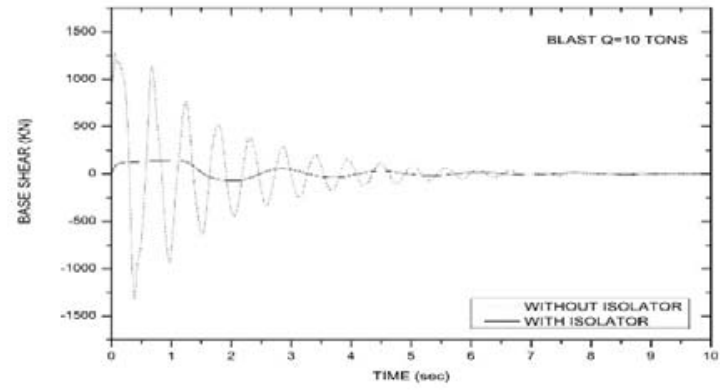

3(a)

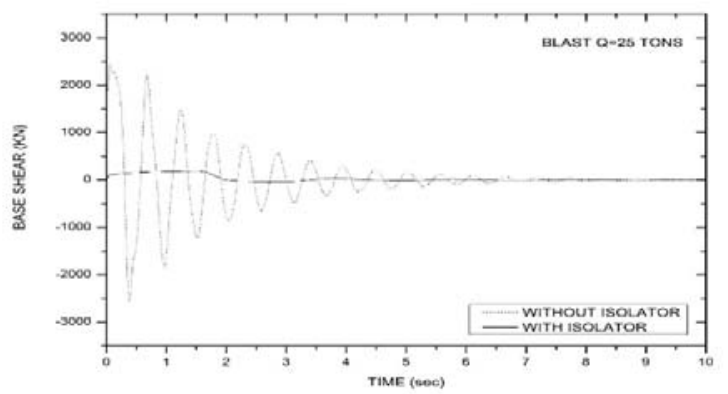

$3(b)$

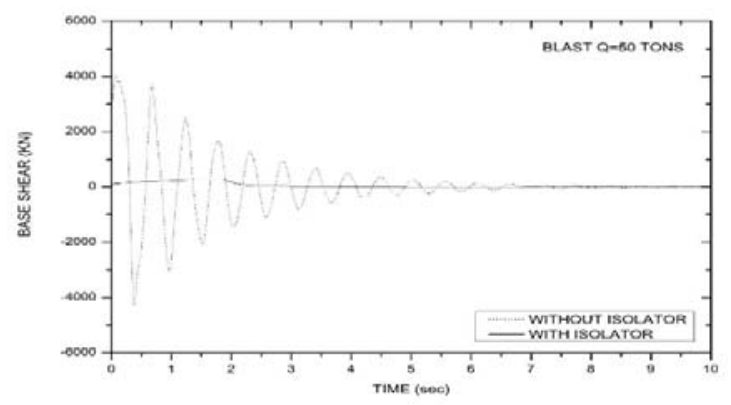

$3(c)$
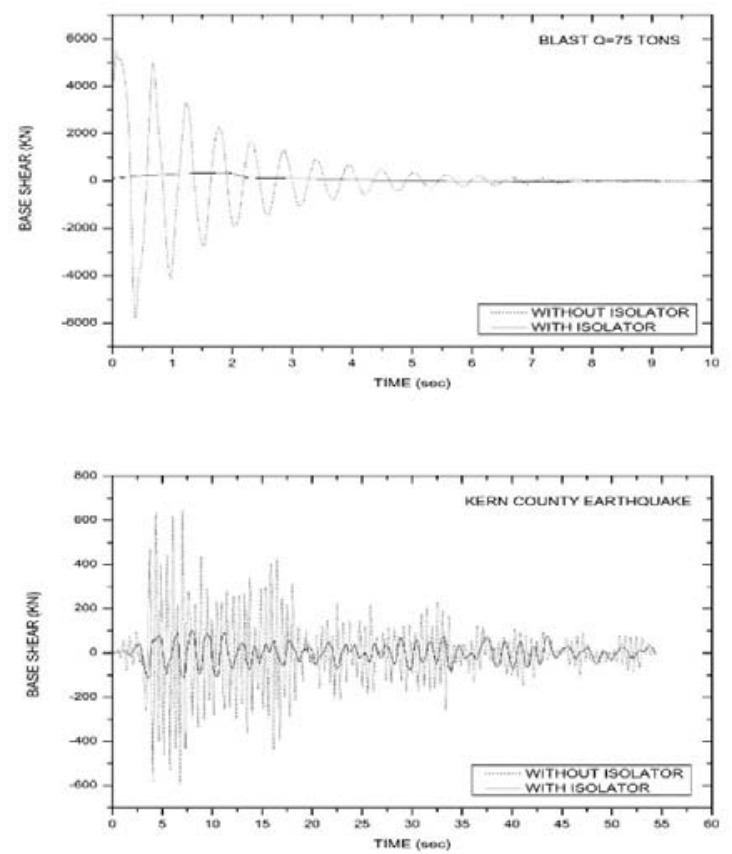

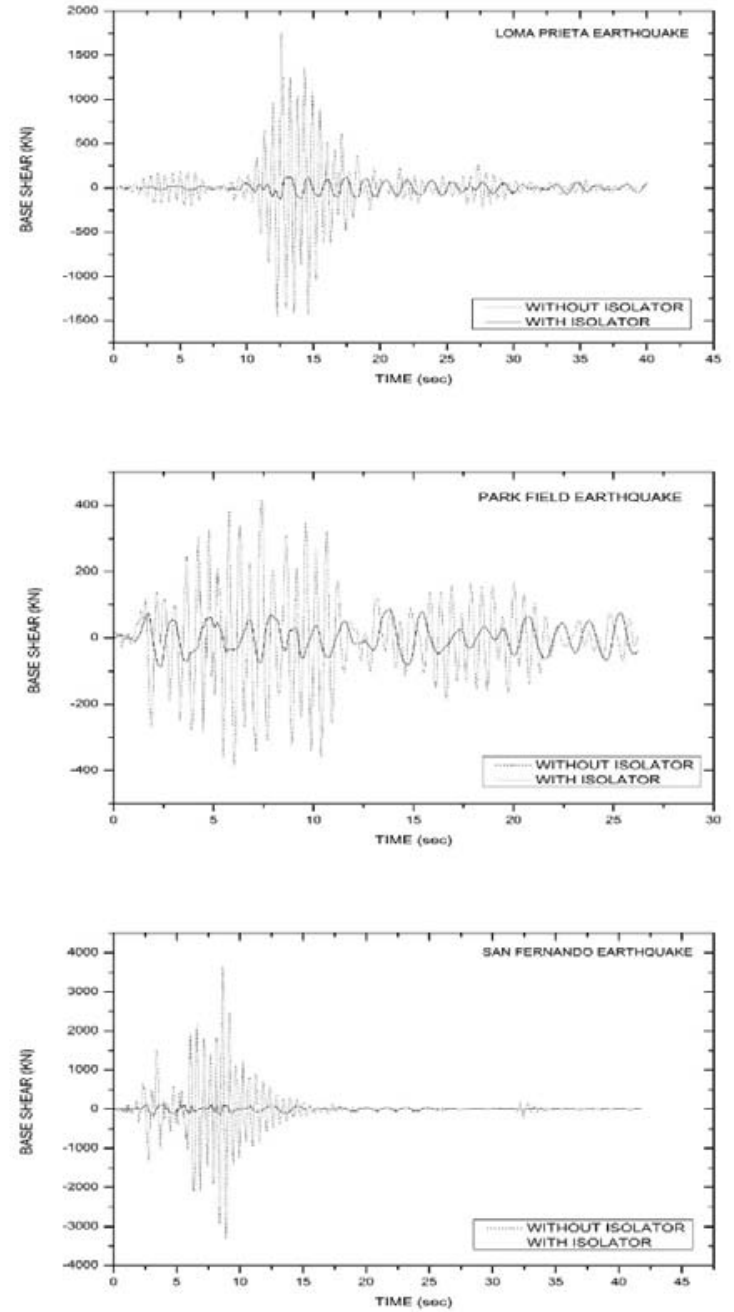

Fig. 3

The U-Shaped Isolator is effective in controlling the structural responses. By supplementing the building with damper causes less deformation for four different Earthquakes and four different blasts which is shown in the form of graphs. Thus, U- Shaped Damper absorbs maximum amount of energy during an Earthquake and Blast vibrations.

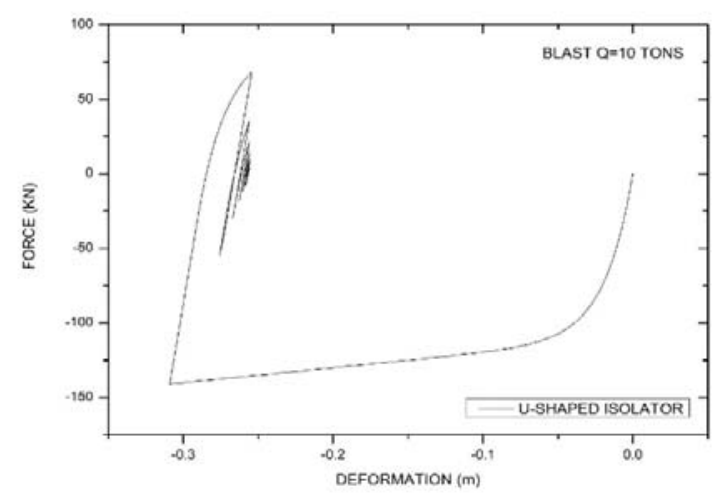

$4(a)$

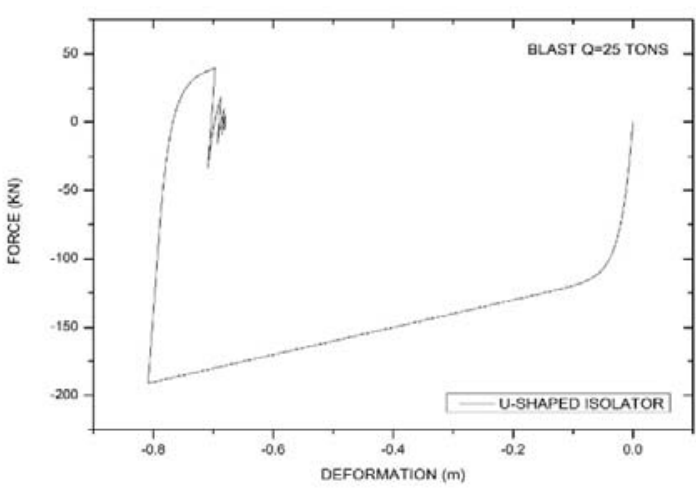

4(b)

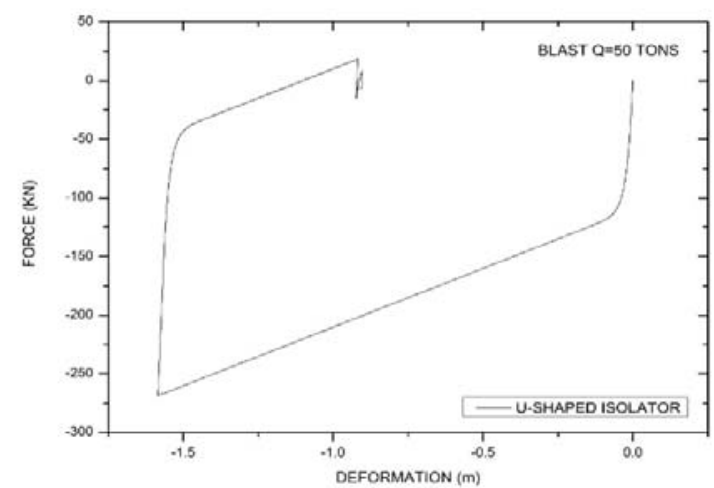

$4(c)$

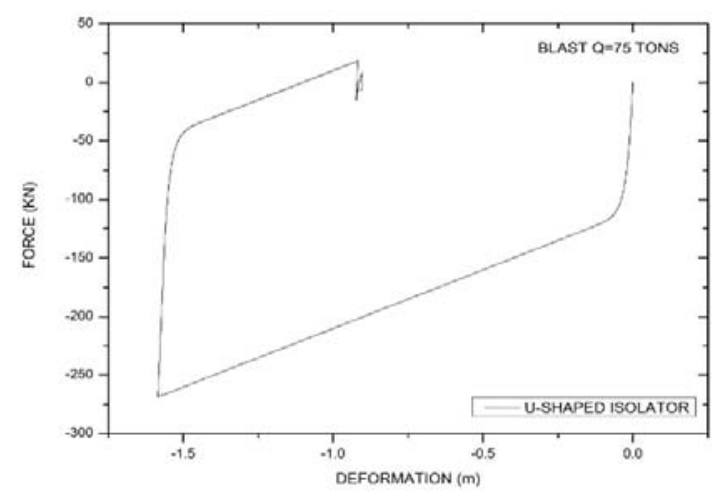

$4(d)$ 

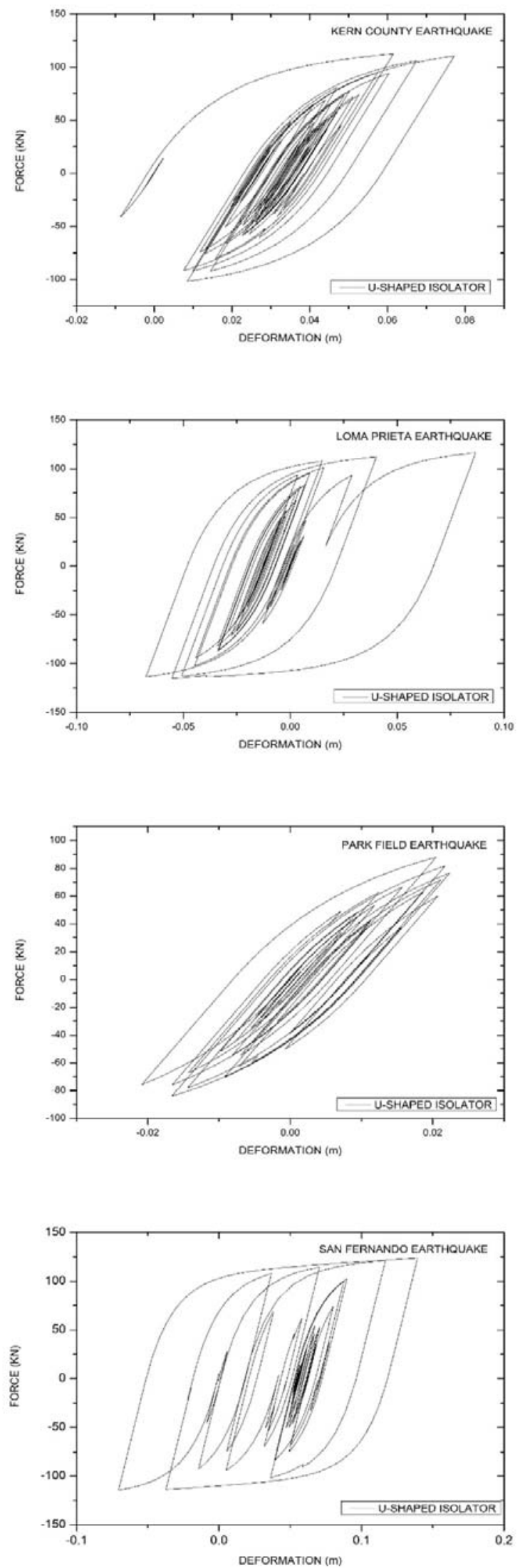

\section{Conclusion}

A 5- story building with isolator and without isolator was analysed using nonlinear time history analysing in SAP 2000 software. The present research evaluates the performance of isolator under seismic and blasting forces. This research aims to study the responses of the structure under four different blast ground motions and four different seismic ground motions, the structural responses are as follows:

By using the supplementary energy device, the top story accelerations were eventually reduced under both seismic and blast induced ground motions.

The base shear values have been reduced for the building with isolator when compared to the building without isolator.

It is concluded that, by the use of isolator the building is subjected to less deformation and, thus, Base Isolation is effective in dissipating maximum amount of energy under seismic and blast induced ground motions.

\section{References}

1. Oggu, Praveen, and K. Gopikrishna, Stru. Vol. 26. Elsevier, (2020)

2. Vinothini, P., and S. Elavenil, Indian Journal of Sci. and Tech. 9,18 (2016)

3. Sunagar, Prashant, et al., IOP Conference Series: Mat. Sci. and Engg. Vol. 814. No. 1. IOP Publishing, (2020)

4. Abdallah, Mohammad International Journal of Civil and Envi. Eng. 14.4 (2020): 117-125.

5. Reddy, N. Omprakash, and Atulkumar Manchalwar.

6. Figuli, Lucia, et al., Procedia engineering 199 2463-2469, (2017)

7. Dutta, Sekhar Chandra, and Rohan Majumder, Advances in Manufacturing Engineering and Materials. Springer, Cham, 485-492 (2019)

8. Kangda, Muhammed Zain, and Sachin Bakre, Arabian J. for Sci. and Eng. 43.4, 1761-1776 (2018)

9. Kangda, Muhammed Zain, and Sachin Bakre, J. of Vibration Eng. \& Tech. 8.1, 1-26 (2020)

10. Kangda, Muhammed Zain, and Sachin Bakre, Arabian J.for Sci. and Eng. 44.5, 4971-4992 (2019)

11. Zhang, Ruiyang, and Brian M. Phillips, J.of Eng. Mech. 142.1, 04015063 (2016)

12. Kelly, J. M., G. Leitmann, and A. G. Soldatos, J. of Optimization Theory and Applications $\mathbf{5 3 . 2}$ 159-180 (1987) 
13. Sravya, G. Jyothi Sri, and Atulkumar Manchalwar, Intl. J. of Recent Tech. and Eng. (IJRTE): 12336-12339 (2020)

14. Hinman EE, Proc., ASCE Spec. Conf. on Stru. for Enhanced Safety and Physical Security, 191202 (1989)

15. Carvalho EM, Battista RC Proc Inst Civ Eng Struct Build 156(3), 243-253 (2003)

16. Kumar R, Choudhury D, Bhargava K, J. Rock Mech. Geotech. Eng. 8(3), 341-349 (2016)

17. Jangid RS, Kelly JM, Earthq. Eng. Struct. Dyns. 30(5), 691-707 (2001)

18. Reddy, N. Omprakash, and A. Manchalwar, E3S Web of Conferences. Vol. 184, EDP Sciences (2020)

19. Manchalwar, Atulkumar, and S. V. Bakre, Intl. J. of Dyns. and Control, 1-10 (2020)

20. Manchalwar, A., and S. V. Bakre, Soil Mech. and Foundation Engineering 57.2, 170-177 (2020)

21. Manchalwar, Atulkumar, and S. V. Bakre, J. of Vib. Eng. \& Tech 7.3, 261-27 (2019)
22. Sravya, G. Jyothi, and A. Manchalwar, E3S Web of Conferences. Vol. 184, EDP Sci. (2020)

23. Manchalwar, A., and S. V. Bakre, J. of The Institution of Engineers (India): Series A 97.4, 415-425 (2016)

24. Nirmala, G., and Atulkumar Manchalwar, E3S Web of Conferences. Vol. 184, EDP Sci. (2020)

25. Lin, Y.C., Wu, F., Wang, Q.-W., Chen, D.-D., Singh, S.K,Vacuum, 151, pp. 283-293, (2018)

26. Kora, P., Kalva, S.R, SpringerPlus, 4 (1), art. no. 481, 19 (2015)

27. Sateesh, N., Sampath Rao, P., Ravishanker, D.V., Satyanarayana, K, Materials Today: Proceedings, 2 (4-5), pp. 2902-2908(2015).

28. Hussaini, S.M., Krishna, G., Gupta, A.K., Singh, S.K, J. of Manf. Processes, 18, pp. 151-158 (2015)

29. Raghunadha Reddy, T., Vishnu Vardhan, B., Vijayapal Reddy.P, Intl. J. of Applied Eng. Res., 11 (5), pp. 3092-3102(2016) 